\title{
Silvia Mostaccio
}

Early Modern Jesuits between Obedience and Conscience during the Generalate of Claudio Acquaviva (1581-1615). Farnham; Burlington: Ashgate, 2014. Pp. 200. Hb, $\$ 124.95$.

Anyone with a significant interest in the history of the Society of Jesus should already be familiar with Silvia Mostaccio's work. An associate professor at the Université Catholique de Louvain (Belgium), Mostaccio has been instrumental in the past few years in redefining our understanding of the central issue of Jesuit obedience. Alongside the work of other Italian scholars (see e.g. Fernanda Alfieri, Claudio Ferlan, Aventure dell'obbedienza nella Compagnia di Gesù. Teorie e prassifra XVI eXIX secolo ([Bologna, Il Mulino, 2012]), her papers on the subject have fast become unavoidable references, reminding historians not only of the inaccuracy of a later vision of Jesuit obedience as merely blind and mechanical, but also of the importance of the internal discussions that accompanied gradual shifts in the culture of obedience. Therefore, the book will not surprise those readers who have been attentive to her work, even if there are many significant additions to be found in the English versions of texts already published elsewhere. It will besides prove immensely useful in making the English-speaking academic public more familiar with Silvia Mostaccio's take on Jesuit and, more generally, early modern cultures of obedience.

The first chapter retraces the importance of obedience as an historical locus, one in which something essential appears about the questions early modern societies faced regarding the relationship between hierarchies of power and individuals. It connects the history of obedience with that of Jesuit government, a central issue during the generalate of Claudio Acquaviva. Mostaccio reminds her reader that Jesuit discussions of abuse of power found their context in the wider political discussion in Europe and in the Society's involvement in these debates. She argues that while the perceptions of obedience that emerged from the discussion of both political government and its relationship to papal authority were rendered obsolete in the realms of politics, they remained central in the reconfiguration of the culture of religious obedience.

The second chapter (a key paper published in 2010 in the Revue d'Histoire Ecclésiastique) returns to the foundational texts of the Society of Jesus to compare the conception of obedience that pervades the Constitutions with that of Ignatius's own writings, and to try to understand both within the context of a larger contemporary literature regarding obedience in different religious orders (particularly the Capuchins and the Barnabites). Insistence on obedience appears connected to the process of institutionalization. In the case of the Jesuits, Silvia Mostaccio argues, a tension emerges in the Constitutions 
between the inner voice of conscience and the requirements of obedience to one's superior. The requirement for obedience went along with a requirement to nourish one's spiritual life, which was oriented towards discernment: in other words, she points to what one might call an actual requirement of agency. Later historiography, influenced both by anti-Jesuit polemic and the Society's own recasting of the theology and spirituality of obedience, has greatly underestimated this tension. Mostaccio reminds us of how central it was and remained for some time for early modern Jesuits.

The third chapter focuses on a most illuminating debate regarding the orthodoxy of the Ignatian theory of obedience in 1585-90. Mostaccio explores the discussion initiated in the Inquisition by an attack on Ignatius's famous "letter on obedience" from a French Jesuit, Julien Vincent. The denunciation came during the pontificate of Sixtus v, a critical time for the Society. It threatened not only a practice of government but in fact the Constitutions themselves. Robert Bellarmine defended the orthodoxy of the Constitutions and of Ignatian spirituality by turning to a more general theory of obedience within a perfect spiritual society. Yet, as Mostaccio shows, his position appears as only one facet of the discussions taking place within the Society: all shared a common issue, namely that of how to hierarchize different types of obedience, and different claims to obedience.

The fourth and final chapter turns to the appropriation of the Ignatian model by women religious, and particularly of the acculturation of individual discernment in sixteenth- and seventeenth-century mysticism. Specifically, the chapter focuses on the relationship between Achille Gagliardi and Isabella Berinzaga in late sixteenth-century Milan. While Isabella's experience was informed by the Spiritual Exercises and the direction of Gagliardi, Gagliardi's reading of the Exercises was in turn affected by Isabella's account of her mystical life. As is well known, their perception that the Society should give greater weight made to spiritual illumination eventually encountered the opposition of Claudio Acquaviva, and more generally ran counter to a movement towards institutionalization within the church. Retracing the relationship between Maria Maddalena de Pazzi and her Jesuit spiritual director Virgilio Cepari, Mostaccio argues that at the beginning of the seventeenth century there existed an idea of interior holiness, not necessarily outwardly manifest. It played a key part in the Jesuit self-understanding, before a later concept of holiness cancelled it out. It also pervaded the relationship between some Jesuits and female mysticism. The chapter closes with an analysis of the famous case of Mary Ward and the less famous case of Catherine de Francheville in mid-seventeenth-century Brittany. Mostaccio insists that the Spiritual Exercises were central in the making of Mary Ward's project and in her fight to 
see it come to life. They were also central to Catherine de Francheville's endeavour: she founded a house exclusively intended for women to undergo the Exercises. Here again, the Exercises appear as central to the construction of new forms of religious agency in Catholic Europe.

To this collection of revised earlier essays, the author has added a conclusion that confronts her own research with recent historiographical developments. She insists on the importance to the history of the Society of Jesus of the long-term negotiation of spiritual empowerment of the individual, on the one hand, with institutional control and institutionalization itself on the other. Indeed, such negotiation certainly appears, as the author writes, as "one of the underlying dynamics" of early modernity.

While one may disagree with such arguments put forward by the author (her perhaps excessive trust in the capacity of the concept of accomodatio to account for how Jesuits navigated the contradictions of early modern Catholicism; an approach to the genesis of modern conscience that can at times appear somewhat teleological), those disagreements are of little importance compared to the contribution made here. Silvia Mostaccio has splendidly illustrated the centrality of obedience for our understanding of early modern religious and political dynamics. Indeed "the unremitting tension" that she highlights, namely that between a growing faith in individual discernment and the insistence on obedience as vital for the functioning of social and political entities, certainly proved essential to early modern societies.

The additions made at the occasion of this publication do not really alter the narrative that was already present in earlier versions of these texts. While one may regret that it should be necessary to have them translated into English to see them reach the audience they deserve, one also cannot but rejoice at seeing this important work in Jesuit history being assured of a much wider remit.

Jean-Pascal Gay

University of Strasbourg

jeanpascalgay@me.com

DOI 10.1163/22141332-00203005-05 